\title{
Multiple Actions of Neurturin Correlate with Spatiotemporal Patterns of Ret Expression in Developing Chick Cranial Ganglion Neurons
}

\author{
Eri Hashino,, ${ }^{1,2}$ Eugene M. Johnson Jr, ${ }^{3}$ Jeffrey Milbrandt, ${ }^{4}$ Marlene Shero, ${ }^{2}$ Richard J. Salvi, ${ }^{2}$ and \\ Christopher S. Cohan ${ }^{1,2}$ \\ ${ }^{1}$ Department of Anatomy and Cell Biology and ${ }^{2}$ Center for Hearing and Deafness, State University of New York at Buffalo, \\ Buffalo, New York 14214, and Departments of 3Neurology, Molecular Biology, and Pharmacology and 4Pathology and \\ Internal Medicine, Washington University School of Medicine, St. Louis, Missouri 63110
}

The neurotrophic effects of neurturin (NRTN) on chick cranial ganglia were evaluated at various embryonic stages in vitro and related to its receptor expression. NRTN promoted the outgrowth and survival of ciliary ganglion neurons at early embryonic (E) stages (E6-E12), trigeminal ganglion neurons at midstages (E9-E16), and vestibular ganglion neurons at late stages (E12-E16). NRTN had no positive effects on cochlear ganglion neurons throughout development. In accordance with the time and order of onset in NRTN responsiveness, Ret protein was first detected in ciliary ganglia at E6, subsequently in trigeminal ganglia at E9, and in vestibular ganglia at E12. Ret was absent in E16 ciliary ganglia as well as in cochlear ganglia at all developmental stages that were tested. Exogenous application of retinoic acid induced NRTN responsiveness and Ret protein expression from E9 vestibular ganglion neurons, suggesting that retinoic acid can regulate Ret protein expression in peripheral sensory neurons in vitro. Ret was confined to the neuron cell body, whereas GFR $\alpha$ was localized predominantly in peripheral and central neurite processes. No noticeable change in GFR $\alpha$ expression was seen in any cranial ganglia throughout the developmental stages that were tested (E6-E16). These results demonstrate that NRTN exerts neurotrophic effects on different cranial ganglia at different developmental stages and that the onset and offset of NRTN responsiveness are regulated mainly by the spatiotemporal patterns of Ret, but not of GFR $\alpha$ receptors. The results also substantiate the recently emerging view that NRTN may be an essential target-derived neurotrophic factor for parasympathetic neurons during development.

Key words: neurturin; GFR $\alpha$; Ret; ciliary; trigeminal; vestibular; cochlear; chicken
Neurturin (NRTN) is a member of the glial cell line-derived neurotrophic factor (GDNF) ligand family, which now comprise three other ligands, GDNF (Lin et al., 1993), persephin (PSPN; Milbrandt et al., 1998) and artemin (ARTN; Baloh et al., 1998). NRTN originally was isolated from Chinese hamster ovary conditioned medium on the basis of its ability to promote the survival of sympathetic neurons (Kotzbauer et al., 1996). Despite a relatively low sequence homology $(42 \%)$, the neurotrophic effects of NRTN strikingly resemble those of GDNF. Both NRTN and GDNF promote the survival of nodose, superior cervical sympathetic, and dorsal root ganglion neurons in vitro (Buj-Bello et al., 1995; Trupp et al., 1995; Kotzbauer et al., 1996). Although accumulating evidence indicates that NRTN acts as a survival factor for several autonomic and sensory neural populations in vitro, the central question of what role NRTN plays in the peripheral nervous system (PNS) development remains to be determined.

NRTN and other members of the GDNF ligand family share a receptor complex, which is composed of a glycosyl-

\footnotetext{
Received April 13, 1999; revised July 8, 1999; accepted July 16, 1999.

This work was supported by National Institutes of Health Grants R01 DC01785 (C.S.C.) and R01 DC01685 (R.J.S.). We thank Ree Dolnick for technical assistance, Dr. Cynthia Dlugos for histological processing, and Dr. Malu Tansey for helpful discussions. We also thank Regeneron Pharmaceuticals, Incorporated, Tarrytown, $\mathrm{NY}$, for providing recombinant BDNF and CNTF.

Correspondence should be addressed to Dr. Eri Hashino, Center for Hearing and Deafness, State University of New York at Buffalo, 215 Parker Hall, Buffalo, NY 14214.

Copyright (C) 1999 Society for Neuroscience $\quad 0270-6474 / 99 / 198476-11 \$ 05.00 / 0$
}

phosphatidylinositol (GPI)-linked ligand-binding protein $(\mathrm{GFR} \alpha)$ and a transmembrane tyrosine kinase receptor, Ret. GDNF and NRTN each bind to GFR $\alpha$. This ligand-binding protein complex then can activate Ret. Four GPI-linked receptors have been cloned thus far and designated as GFR $\alpha 1$ (Jing et al., 1996; Treanor et al., 1996), GFR $\alpha 2$ (Baloh et al., 1997; Buj-Bello et al., 1997; Klein et al., 1997), GFR $\alpha 3$ (Jing et al., 1997; Baloh et al., 1998; Masure et al., 1998; Worby et al., 1998), and GFR $\alpha 4$ (Thompson et al., 1998). Several lines of evidence suggest that GDNF, NRTN, ARTN, and PSPN have the highest binding affinity to $\mathrm{GFR} \alpha 1, \mathrm{GFR} \alpha 2, \mathrm{GFR} \alpha 3$, and GFR $\alpha 4$, respectively (Baloh et al., 1997, 1998; Jing et al., 1997; Thompson et al., 1998), although NRTN also can signal via the GFR $\alpha 1-$ Ret receptor complex (Creedon et al., 1997). Extensive efforts recently have been initiated to elucidate the downstream signaling of the GDNF ligand family after receptor binding. GDNF, as well as NRTN, stimulates the Ras/MAP kinase pathway via Ret (Ohiwa et al., 1997). In addition, a recent study suggests that exogenous $\mathrm{Ca}^{2+}$ is required for GDNF/NRTN-mediated Ret activation (Nozaki et al., 1998). Nevertheless, little is known about how NRTN and GDNF interact with the receptor complex and activate intracellular signaling cascades.

Recent evidence suggests that GDNF acts as a survival factor for certain PNS neurons only at early developmental stages and for other PNS neurons at late developmental stages (Buj-Bello et al., 1995; Molliver et al., 1997). These observations raise the question of whether NRTN acts on PNS neurons at specific developmental stages and, if so, whether the stage-specific effects 
are regulated by its receptor expression. In the present study the neurotrophic effects of NRTN on chick ciliary, trigeminal, vestibular, and cochlear ganglia were examined at various embryonic stages by organotypic and dissociated neuron cultures. In addition, developmental changes in the expression of GFR $\alpha$ and Ret, the receptor components for NRTN, were examined in the cranial ganglia and related to those in NRTN responsiveness. Finally, the effects of retinoic acid on NRTN responsiveness were examined in light of the observation that retinoic acid can modulate neurotrophin responsiveness in developing PNS neurons by regulating receptor expression (von Holst et al., 1997).

\section{MATERIALS AND METHODS}

Organotypic culture. White Leghorn chick embryos at embryonic day 6 (E6), E9, E12, and E16 were used in the present study. The embryos were decapitated, and their vestibular (VG), cochlear (CG), ciliary (CLG), and trigeminal ganglia (TG) were dissected in HBSS under a dissection microscope. One ganglion was placed in the center of a well of 24-well culture dishes coated with $0.02 \%$ poly-D-lysine (Becton Dickinson, Bedford, MA). The basal medium was a serum-free DMEM/F12 (Life Technologies, Grand Island, NY) supplemented with 10 mM HEPES, $100 \mathrm{U} / \mathrm{ml}$ penicillin, and 1\% ITS plus PREMIX (Becton Dickinson). The medium contained NRTN $(1,10,50$, or $100 \mathrm{ng} / \mathrm{ml}$ ), PSPN (50 or 100 $\mathrm{ng} / \mathrm{ml}$ ), BDNF, CNTF (50 ng/ml; both kindly provided by Regeneron, Tarrytown, NY), or no factor (control). Some explants were incubated in a combination of NRTN (50 or $100 \mathrm{ng} / \mathrm{ml})$ and $10 \mu \mathrm{M}$ all-trans-retinoic acid (dissolved from $10 \mathrm{~mm}$ stock in DMSO; Sigma, St. Louis, MO). The ganglia were incubated with $5 \% \mathrm{CO}_{2}$ at $37^{\circ} \mathrm{C}$ for $3 \mathrm{~d}(\mathrm{E} 6, \mathrm{E} 9$, and $\mathrm{E} 12$ ganglia) or $5 \mathrm{~d}$ (E16 ganglia). The outgrowth of neurites was documented photographically with a Nikon Diaphot inverted microscope. The $35 \mathrm{~mm}$ photographic negatives were digitized with a Nikon Cool Scan film scanner. The magnitude of neurite outgrowth was evaluated quantitatively and described as an average of the radial distance of neurite tips from the explant. Four radial lines drawn from the center of the explant divided the field into four equal sectors $\left(90^{\circ} /\right.$ sector $)$. The length of outgrowth was measured from the edge of the explant to the distal tip of the longest neurites in each sector. The mean outgrowth was calculated as the average length of neurites for all sectors of each explant. Six to 14 ganglia for each experimental group were obtained from at least two separate experiments and were used for measurement.

Neurofilament staining. The explants were fixed with $4 \%$ paraformaldehyde for $30 \mathrm{~min}$, and their neurite processes were verified by immunohistochemical staining with a neurofilament antibody. The specimens were incubated at room temperature in blocking solution [1\% Triton $\mathrm{X}-100$ and $3 \%$ bovine serum albumin (BSA) in PBS] for $1 \mathrm{hr}$ and subsequently with a $160 \mathrm{kDa}$ neurofilament antibody (clone RMO-270, 1:2000; Zymed, San Francisco, CA) diluted in blocking solution for $2 \mathrm{hr}$. Endogenous biotin was inhibited by NeurtrAvidin $(0.1 \mathrm{mg} / \mathrm{ml}$ in blocking solution; Pierce, Rockford, IL) for $15 \mathrm{~min}$ and $2 \mathrm{~mm}$ D-biotin (Pierce) for $1 \mathrm{hr}$. Thereafter, the specimens were incubated with biotinylated antimouse IgG (5 $\mu \mathrm{l} / \mathrm{ml}$ in blocking solution; Vector Laboratories, Burlingame, CA) for $1 \mathrm{hr}$, and the reaction product was visualized by peroxidase-conjugated ExtrAvidin (1:1000; Sigma) with TrueBlue (Kirkegaard \& Perry, Gaithersburg, MD) as a substrate.

Dissociated neuron culture. CLG, TG, and VG were removed from E9 chick embryos in sterile conditions. Sixteen to 20 ganglia were collected and incubated in $0.1 \%$ trypsin in calcium-, magnesium-free HBSS for $30-45 \mathrm{~min}$ at $37^{\circ} \mathrm{C}$. The enzymatic reaction was stopped by adding ice-cold DMEM/F-12 and heat-inactivated horse serum. The ganglia were transferred to defined medium and triturated with a fire-polished glass pipette. The dissociated cells were plated on a $60 \mathrm{~mm}$ untreated Petri dish for $2 \mathrm{hr}$ to enrich the neuronal population. Then the cells were plated on 24-well tissue culture plates coated with poly-D-lysine (200 $\mu \mathrm{g} / \mathrm{ml})$ and laminin $(50 \mu \mathrm{g} / \mathrm{ml}$; Life Technologies) at the average density of 300 cells $/ \mathrm{mm}^{2}$. Cells were incubated in serum-free medium supplemented with NRTN, CNTF, BDNF (50 ng/ml each), a combination of NRTN and retinoic acid, or no factor (control). Neuronal survival was determined $2 \mathrm{~d}$ after the start of incubation by counting phase-bright cells with neuronal morphology. Surviving neurons were verified further by the Live/Dead viability assay kit (Molecular Probes, Eugene, OR) according to the manufacturer's instructions. Viable neurons were counted with a grid ocular reticule covering an area of $0.5 \mathrm{~mm}^{2}$. For each well, approximately five randomly selected fields (three to four wells per group per experiment) were counted. Data were collected from at least three separate experiments for each group. Some of the cultures were fixed with $4 \%$ paraformaldehyde for $30 \mathrm{~min}$ and labeled with a Ret antibody.

Immunohistochemistry. E6, E9, E12, and E16 chick embryos were fixed in $4 \%$ paraformaldehyde $/ 0.1 \%$ glutaraldehyde overnight at $4^{\circ} \mathrm{C}$ and embedded in paraffin. Horizontal sections $(10 \mu \mathrm{m})$ of the whole heads were cut and mounted on Superfrost plus slides (VWR Scientific, West Chester, PA). Sections that included vestibular, cochlear, ciliary, or trigeminal ganglia were stained with $1 \%$ toluidine blue or the indicated antibodies. After deparaffinization, the sections were treated with $0.3 \% \mathrm{H}_{2} \mathrm{O}_{2}$ in methanol for $10 \mathrm{~min}$ to inactivate the endogenous peroxidase. The sections subsequently were incubated at room temperature in blocking solution $[0.3 \%$ Triton X-100, 5\% BSA, and $10 \%$ normal horse serum in hi-salt $(1.8 \% \mathrm{NaCl}) \mathrm{PBS}]$ for $1 \mathrm{hr}$ and then either with anti-Ret $(1: 100$; Santa Cruz Biotechnology, Santa Cruz, CA) or with anti-GFR $\alpha$ (antiGDNFR $\alpha$, clone 17, 1:500; Transduction Laboratories, Lexington, KY) in blocking solution at $4^{\circ} \mathrm{C}$ overnight. The GFR $\alpha$ antibody that is raised against GFR $\alpha 1$ cross-reacts with GFR $\alpha 2$ and was used in the present study for probing both GFR $\alpha 1$ and GFR $\alpha 2$. The amino acid sequences for both human Ret and rat GFR $\alpha$ epitopes differ from the corresponding chicken sequences by only a single amino acid. Thereafter, the sections were incubated with biotinylated secondary antibody $(5 \mu \mathrm{l} / \mathrm{ml}$; Vector Laboratories) in blocking solution for $1 \mathrm{hr}$, and the reaction product was visualized by the biotin-avidin-HRP detection system (ABC Elite kit, Vector Laboratories), using 3,3'-diaminobenzidine (DAB) as a substrate. To confirm the specificity of the staining, we processed sections either by omission of incubation with a primary antibody or with the primary antibody preabsorbed with a blocking peptide. To count the number of Ret-positive neurons, we digitized and analyzed every 10th section throughout the entire ganglion from at least three animals at each developmental stage.

Western blot analysis. Cranial ganglia (ciliary, trigeminal, and vestibular ganglia) or whole brains were dissected from E9 chick embryos. Tissues were homogenized with a 25 -gauge syringe needle in $300 \mu \mathrm{l}$ of lysis buffer [(containing in mM) 10 HEPES, pH 7.4, $10 \mathrm{KCl}, 0.2$ EDTA, 1 DTT, and 0.5 Pefabloc (Roche) plus $10 \mu \mathrm{g} / \mathrm{ml}$ aprotinin]. After $15 \mathrm{~min}$ on ice, Nonidet P-40 was added to a final concentration of $0.65 \%$. Samples were centrifuged for $10 \mathrm{~min}$ at $4^{\circ} \mathrm{C}$, and the resulting supernatant was added to the sample buffer. The protein concentration was determined via the BCA protein assay (Pierce). In each lane $10-15 \mu \mathrm{g}$ of protein was run on a $10 \%$ SDS-polyacrylamide gel and transferred to a polyvinylidene difluoride membrane (Bio-Rad, Hercules, CA). The blots were incubated sequentially in blocking buffer (Tropix, Bedford, MA), anti-GFR $\alpha$ antibody (1:3000), and alkaline phosphatase-conjugated antimouse IgG. The blots were visualized with the Western-Star chemiluminescent detection system (Tropix) according to the manufacturer's instructions.

\section{RESULTS}

\section{Ciliary, trigeminal, and vestibular ganglion neurons have different onset times for NRTN responsiveness}

The CLG neurons extended a robust outgrowth $(2489 \pm 134 \mu \mathrm{m})$ in the presence of $50 \mathrm{ng} / \mathrm{ml} \mathrm{NRTN}$ at E6, the earliest developmental stage that was examined (Fig. 1). An extensive neurite outgrowth also was observed from E9 CLG explants that were grown in medium containing NRTN (Figs. 1, 2). Although CLG neurons showed a significant outgrowth with NRTN at E12, the average length of neurites of E12 CLG neurons (1647 $\pm 236 \mu \mathrm{m})$ was significantly shorter than that of E6 or E9 CLG neurons. By striking contrast to the extensive outgrowth at E6-E12, no outgrowth was observed from E16 CLG with NRTN at 10-100 $\mathrm{ng} / \mathrm{ml}$ in comparison to controls (Fig. 1). Unlike the CLG neurons, TG neurons did not respond to NRTN at E6 (Fig. 1). By E9, however, TG neurons had become responsive to NRTN, inducing a significant outgrowth $(1730 \pm 129 \mu \mathrm{m}$; Figs. 1, 2). The average outgrowth of TG neurons in response to NRTN was greater at E12 $(2342 \pm 186 \mu \mathrm{m})$ than at E9, and the magnitude of outgrowth was sustained out to E16 (1901 $\pm 139 \mu \mathrm{m}$; Fig. 1). Qualitatively, a greater number of neurites were observed from E12 TG ex- 

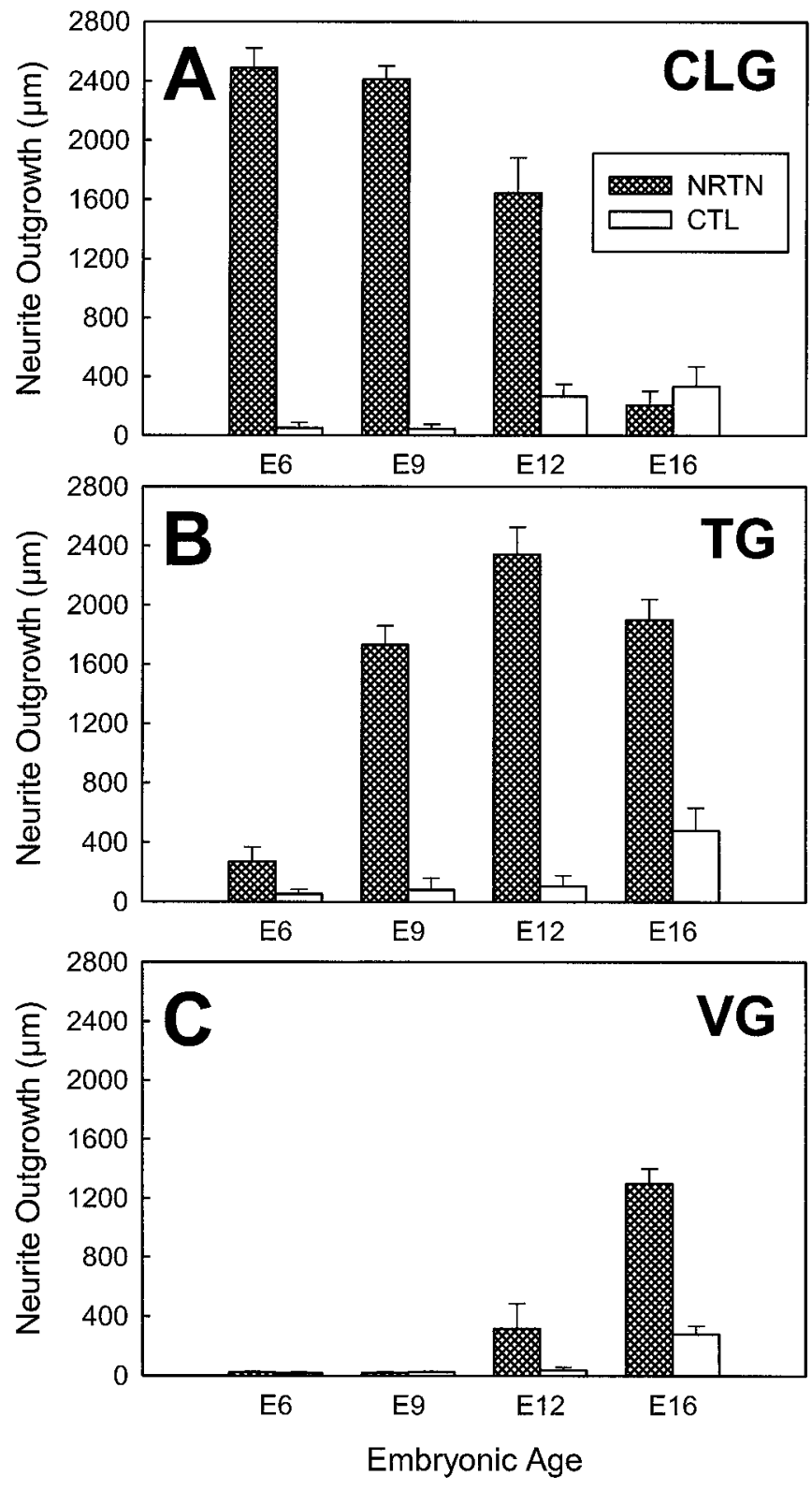

Figure 1. Changes in the effects of NRTN on neurite outgrowth from cranial ganglion explants during development. Each graph depicts the average length of neurites $( \pm \mathrm{SE})$ from ciliary $(C L G ; A)$, trigeminal $(T G$; $B)$, and vestibular $(V G ; C)$ ganglion explants cultured with NRTN (50 $\mathrm{ng} / \mathrm{ml}$ for ciliary ganglia and $100 \mathrm{ng} / \mathrm{ml}$ for trigeminal and vestibular ganglia) in comparison with control explants cultured in the absence of NRTN; shown after 3 d (E6, E9, E12) or 5 d (E16) of incubation. $A$, NRTN elicits a neurite outgrowth from E6, E9, and E12 ciliary ganglia, whereas no positive effect was observed from E16 ciliary ganglia. $B$, NRTN has little effect on E6 trigeminal ganglia but promotes an extensive outgrowth from E9-E16 trigeminal ganglia. $C$, Unlike ciliary or trigeminal ganglia, vestibular ganglia respond to NRTN only at E12 and E16. $n=9,6,9,6,6,12,7$, and 12 (from left, for CLG); $n=8,6,11,6$, $8,11,6$, and 10 (from left, for TG); $n=6,6,8,11,6,14,8$, and 12 (from left, for $\mathrm{VG})$.

plants than from E9 TG explants (Fig. 2). Temporal changes in the sensitivity of VG neurons to NRTN differed from those of CLG and TG neurons. NRTN did not promote neurite outgrowth from E6 nor E9 VG neurons (Figs. 1, 2). VG neurons, however, showed a significant outgrowth in the presence of NRTN at E12 $(316 \pm 169 \mu \mathrm{m})$, and neurite length increased further at E16
(1298 $\pm 100 \mu \mathrm{m}$; Figs. 1, 2) than at E12. Interestingly, NRTN had no positive effects on $\mathrm{CG}$, which are located near the $\mathrm{VG}$, at all developmental stages that were tested (E9-E16) (Fig. 2).

The NRTN-induced neurite outgrowth from various cranial ganglia was dose-dependent, with the saturation point $\sim 50-100$ $\mathrm{ng} / \mathrm{ml}$ (Fig. 3). The total length of neurites from E9 CLG increased monotonically with the concentration of NRTN up to 50 $\mathrm{ng} / \mathrm{ml}$, at which point the outgrowth reached a maximal value. NRTN at $100 \mathrm{ng} / \mathrm{ml}$ promoted an equivalent outgrowth from the CLG neurons, whereas NRTN at $1 \mathrm{ng} / \mathrm{ml}$ had little effect on the neuron outgrowth. At this stage, TG neurons also showed dosedependent responses to NRTN. NRTN at $10 \mathrm{ng} / \mathrm{ml}$ or higher concentrations elicited a significant outgrowth from the E9 TG neurons. E16 VG neurons showed a significant outgrowth in response to NRTN at concentrations between 10 and $100 \mathrm{ng} / \mathrm{ml}$, and a maximal outgrowth was observed at $100 \mathrm{ng} / \mathrm{ml}$.

To test the specificity of the neurotrophic effects, we compared the magnitude of neurite outgrowth with NRTN (50-100 ng/ml) to that with other neurotrophic factors (Fig. 4). E9 CLG neurons showed an extensive outgrowth $(2069 \pm 184 \mu \mathrm{m})$ in the presence of $50 \mathrm{ng} / \mathrm{ml} \mathrm{CNTF}$, the only known survival factor for CLG neurons (Lin et al., 1989). The outgrowth of CLG neurons with CNTF was comparable to that with NRTN. In contrast, the CLG neurons showed virtually no outgrowth in the presence of BDNF or in the absence of a neurotrophic factor (control). PSPN (50 or $100 \mathrm{ng} / \mathrm{ml}$ ) had no effect on E9 CLG neuron outgrowth (data not shown). Interestingly, E16 CLG neurons showed a significant outgrowth in response to CNTF at $50 \mathrm{ng} / \mathrm{ml}$ (data not shown), which contrasts with no outgrowth in the presence of NRTN at E16 (see Fig. 1). The neurite outgrowth of E9 TG neurons with NRTN was much greater than that with CNTF $(350 \pm 83 \mu \mathrm{m})$ but was less than that with $\operatorname{BDNF}(2414 \pm 198 \mu \mathrm{m})$. E9 VG neurons showed a significant outgrowth with BDNF but did not respond to CNTF or NRTN.

To verify whether NRTN can promote the survival of the cranial ganglion neurons, we performed a survival assay with the dissociated neuron culture (Fig. 5). In medium containing NRTN, the majority of E9 CLG neurons (83\%) was viable after $48 \mathrm{hr}$ in culture, compared with $2.5 \%$ survival in the control culture. CNTF also promoted the survival of CLG neurons at a degree equivalent to NRTN. In contrast, only $30 \%$ of dissociated E9 TG neurons were viable after $48 \mathrm{hr}$ in culture with NRTN. This is consistent with our observation that a limited number of neurite processes were observed from E9 TG explants cultured with NRTN (see Fig. 2). The surviving TG neurons showed Ret immunoreactivity, which was absent in non-neuronal cells or neurons probed with the peptide-absorbed antibody (Fig. 5C). A significantly greater number of the TG neurons (51\%) survived in the presence of BDNF. The failure of BDNF to promote the survival of approximately one-half of the TG neurons presumably is attributable to the fact that TG neurons of neural crest origin are NGF-dependent.

\section{Different cranial ganglia have different onset and offset times for Ret expression}

To explore the possibility that the differential effects of NRTN on CLG, TG, and VG neurons are attributable to differential developmental regulation of its receptor expression, we examined Ret protein expression in the cranial ganglia. We found that Ret protein expression changes spatiotemporally in chick cranial ganglia during development. At E6, CLG neurons showed positive Ret staining, whereas TG and other cranial ganglia were devoid of 

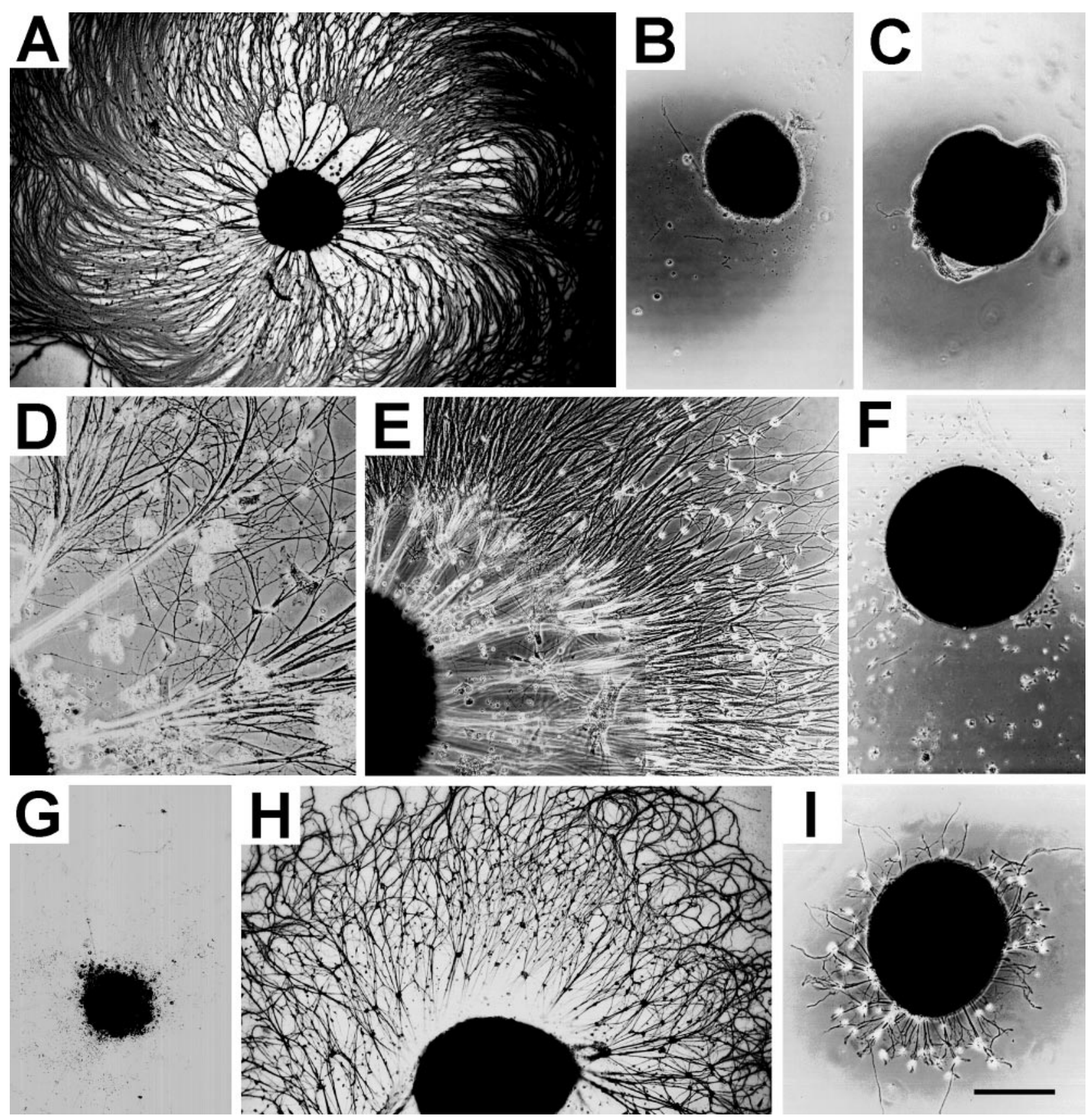

Figure 2. Comparison of neurite outgrowth from ciliary, trigeminal, vestibular, and cochlear ganglion explants elicited by NRTN at different embryonic stages. $A, B$, E9 ciliary ganglion explant with $(A)$ or without $(B) \mathrm{NRTN}$ at $50 \mathrm{ng} / \mathrm{ml}$. $C$, E16 ciliary ganglion explant with NRTN at $100 \mathrm{ng} / \mathrm{ml}$. $D, E$, E9 $(D)$ and E12 $(E)$ trigeminal ganglion explant cultured with NRTN at $100 \mathrm{ng} / \mathrm{ml} . F$, E16 cochlear ganglion explant with NRTN at $100 \mathrm{ng} / \mathrm{ml}$. $G$, E9 vestibular ganglion explant with NRTN at $100 \mathrm{ng} / \mathrm{ml} . H, I$, E16 vestibular ganglion explant grown with NRTN at $100 \mathrm{ng} / \mathrm{ml}(H)$ or $10 \mathrm{ng} / \mathrm{ml}(I)$. Note that NRTN induces an extensive outgrowth from the E9, but not from E16, ciliary ganglia. In contrast, NRTN has positive effects on E16, but not E9, vestibular ganglia. NRTN has no effect on E16 cochlear ganglion explant outgrowth. The culture was immunostained with a neurofilament antibody $(A$, $G, H)$ or unstained phase-contrast micrographs $(B-F, I)$. Scale bar (shown in $I$ ): $A-C, F-I, 500 \mu \mathrm{m} ; D, E, 260 \mu \mathrm{m}$.

Ret staining (data not shown). At E9, a uniform positive staining was observed in virtually all CLG neurons (Figs. 6, 7). In contrast, intense Ret immunoreactivity was observed only in a subpopulation of TG neurons. Ret-positive neuron cell bodies were localized in the rostral portion of the TG (Figs. 6, 8). Ret labeling was absent in E9 VG as well as CG neurons (Fig. 6). Intense staining of Ret in TG, in contrast with negative staining in VG, was seen consistently in the same sections, clearly indicating differential expression of Ret protein in midstage developing chick cranial ganglia. A count of the neuron number revealed that $\sim 33 \%$ of TG neurons were Ret-positive at E9 (Fig. 7). By E12, however, the vast majority of TG neurons had become Ret-positive (Figs. 7, 8). At this time, $\sim 26 \%$ of $\mathrm{VG}$ neurons also showed positive staining with Ret (Fig. 7). By contrast, Ret staining in CLG decreased from $100 \%$ at E9 to $27 \%$ at E12. In addition, staining was faint even in Ret-positive CLG neurons. At E16 the vast majority of TG as well as VG neurons was positive with Ret staining (Figs. 7, 8), whereas Ret staining was absent in CG (data not shown). CLG 

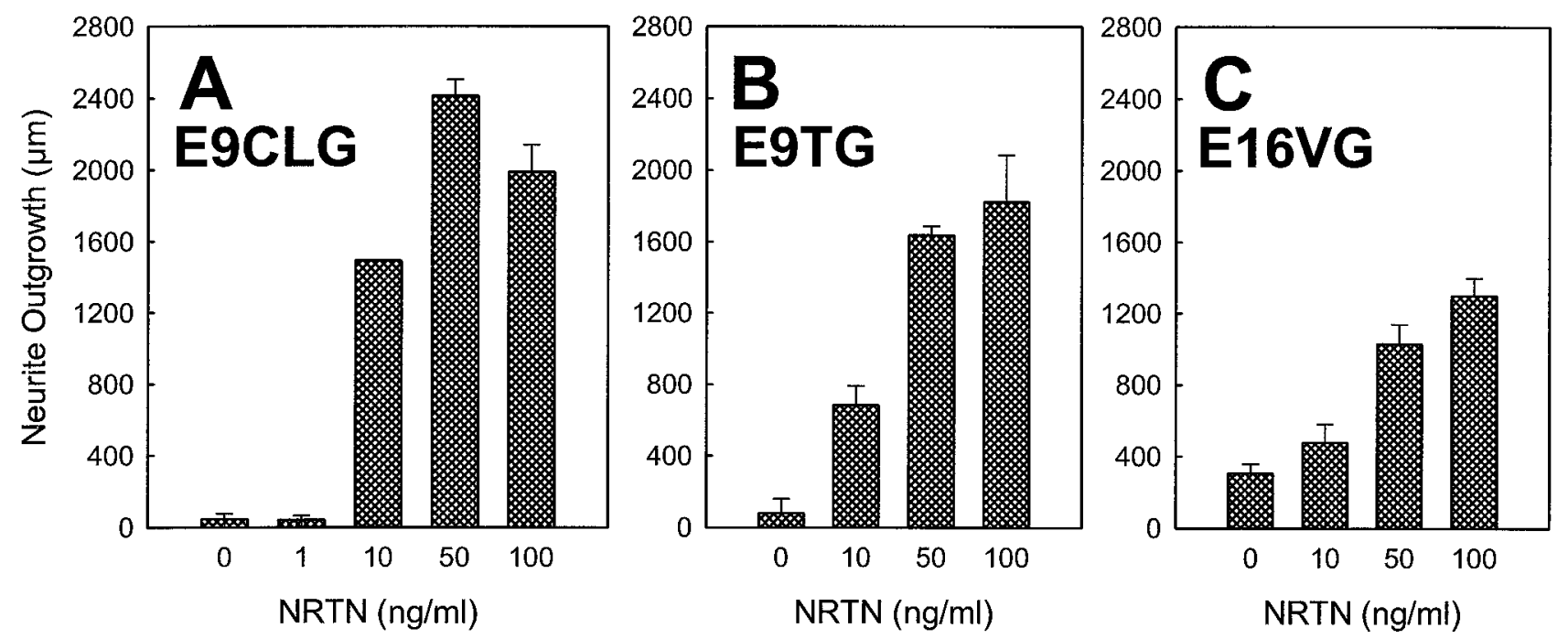

Figure 3. Dose-responses of the E9 ciliary $(A)$, E9 trigeminal $(B)$, and E16 vestibular $(C)$ ganglion explants to NRTN. Each graph shows the average neurite outgrowth from each ganglion cultured with NRTN at concentrations ranging from 0 to $100 \mathrm{ng} / \mathrm{ml}$ for $3 \mathrm{~d}(A, B)$ or $5 \mathrm{~d}(C)$. The E9 ciliary ganglion shows a monotonic increase in neurite outgrowth in response to NRTN up to the concentration of $50 \mathrm{ng} / \mathrm{ml}$, beyond which the magnitude of neurite outgrowth decreases. The trigeminal as well as vestibular ganglia show a monotonic increase in neurite outgrowth in response to NRTN, with a maximum outgrowth at $100 \mathrm{ng} / \mathrm{ml} . n=6,6,6,9$, and 6 (from left, for CLG); $n=6,9,6$, and 6 (from left, for TG); $n=11,7,6$, and 8 (from left, for VG).

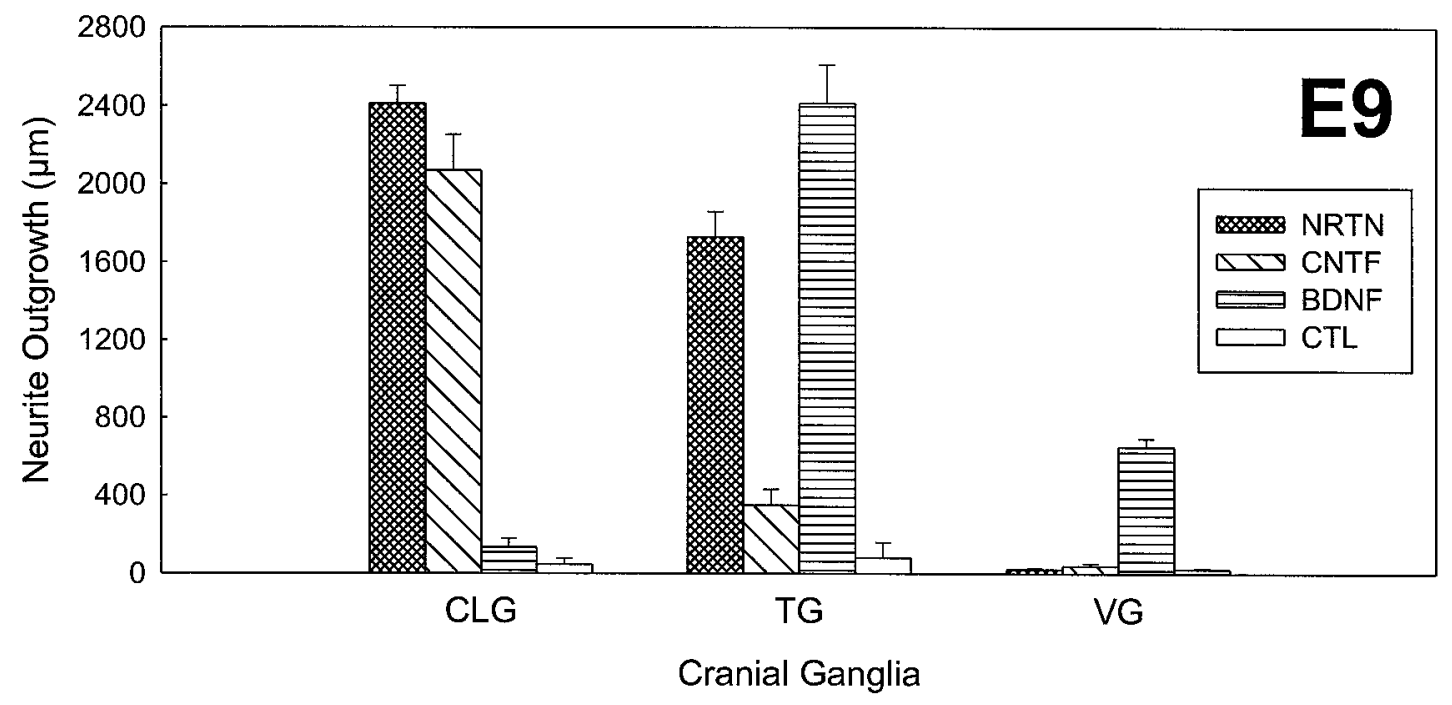

Figure 4. Quantification of the effects of various neurotrophic factors on neurite outgrowth from E9 chick cranial ganglion explants. The graph shows the average neurite length $( \pm \mathrm{SE})$ for ciliary, trigeminal, and vestibular ganglion explants grown in medium containing NRTN $(50 \mathrm{ng} / \mathrm{ml})$, CNTF $(50$ $\mathrm{ng} / \mathrm{ml}$ ), or BDNF (50 ng/ml) for $3 \mathrm{~d}$ in comparison with control ganglia cultured in the absence of the factors. Ciliary ganglia are responsive to NRTN as well as to CNTF, trigeminal ganglia to NRTN as well as to BDNF, and vestibular ganglia only to BDNF. Note that the three cranial ganglia respond to the neurotrophic factors in a distinctive and specific manner. $n=9,6,6$, and 6 (from left, for CLG); $n=11,7,8$, and 6 (from left, for TG); $n=8$, 9, 12, and 11 (from left, for VG).

neurons, which showed prominent staining at E9, also were devoid of Ret staining at E16 (Figs. 7, 8).

Because GFR $\alpha$ receptors comprise another component of the functional NRTN/GDNF receptor complex, we examined the spatiotemporal changes in GFR $\alpha$ expression in cranial ganglia. Because the rat epitope for the GFR $\alpha$ antibody (clone 17) has a $95 \%$ identity to the corresponding chicken sequence, we validated cross-reactivity of the antibody against chicken GFR $\alpha$ by Western blots. The antibody labeled double bands located between 45 and $60 \mathrm{kDa}$ in lysate prepared from E9 chick cranial ganglia or whole brain (Fig. $8 D$ ). The positions of these immunoreactive bands coincided with those obtained from rat pituitary lysate, thus confirming the cross-reactivity of the antibody. Immunohistochemical staining of E9 cranial ganglia with a GFR $\alpha$ antibody demonstrated striking differences in localization between GFR $\alpha$ and Ret. First, GFR $\alpha$ and Ret were not colocalized in certain ganglia at a given developmental stage. GFR $\alpha$ was present in all CLG, TG, VG, and CG, whereas Ret was present only in CLG and TG (see Fig. 6). Second, subcellular localization of GFR $\alpha$ was different from and complementary to that of Ret in each ganglion. Intense staining of GFR $\alpha$ was observed in neurites emerging from the neuron cell body and also on the plasma membrane, with little staining in perikarya (Fig. 8). The prominent localization of GFR $\alpha$ in neurites contrasts with a complete 


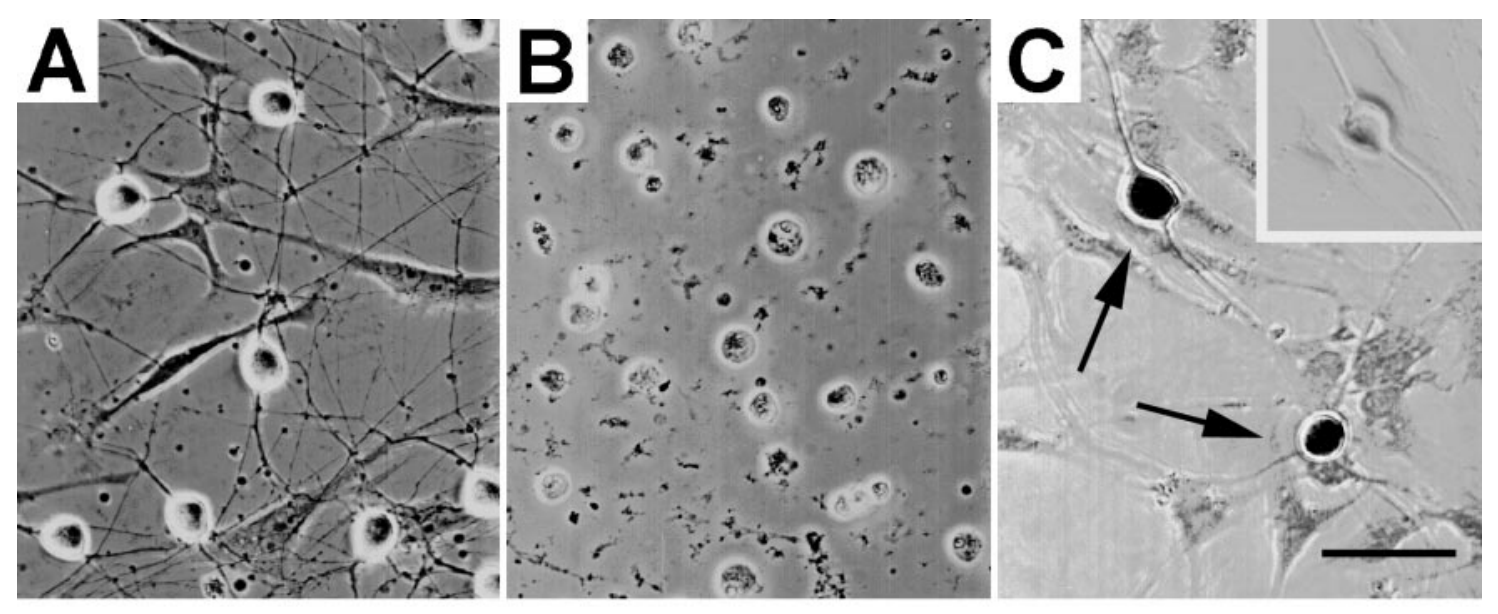

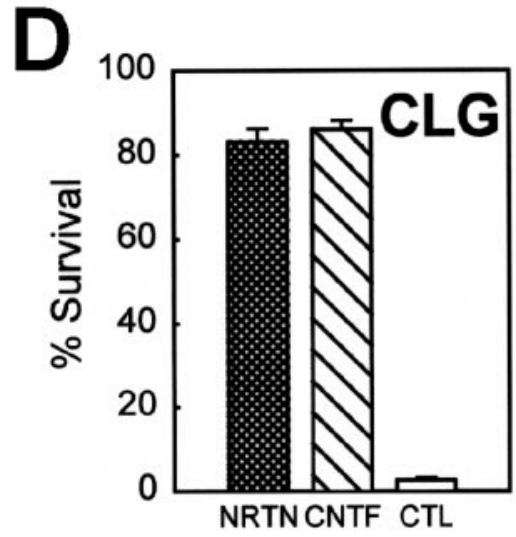

Factors

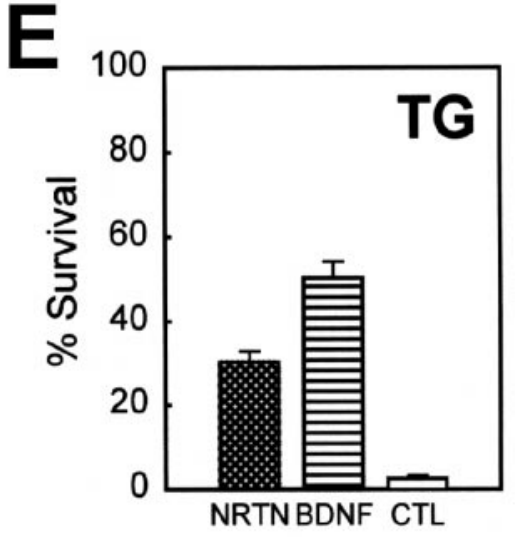

Factors

Figure 5. Effects of NRTN on the survival of E9 ciliary and trigeminal ganglion neurons. $A$, Dissociated E9 ciliary ganglion neurons grown in the presence of $50 \mathrm{ng} / \mathrm{ml}$ NRTN. $B$, Dissociated E9 ciliary ganglion neurons grown in the absence of trophic factors. $C$, Dissociated E9 trigeminal ganglion neurons grown for $2 \mathrm{~d}$ in the presence of $50 \mathrm{ng} / \mathrm{ml} \mathrm{NRTN}$ and subsequently stained for Ret. All cells with neuronal morphology are positive with Ret staining (arrows), whereas flat non-neuronal cells are devoid of staining. A neuron probed with the primary antibody that was preincubated with a blocking peptide shows no staining (inset). Scale bar, $50 \mu \mathrm{m}$. D, Survival of E9 ciliary ganglion neurons in the presence of $50 \mathrm{ng} / \mathrm{ml}$ NRTN or CNTF in comparison with control (no factor). E, Survival of E9 trigeminal ganglion neurons in the presence of $50 \mathrm{ng} / \mathrm{ml}$ NRTN or BDNF in comparison with control. Results are expressed as the percentage of the neurons that survived after $48 \mathrm{hr}$ in culture ( \pm SE). Note that the majority of E9 ciliary ganglion neurons is supported by NRTN $(D)$, whereas only a subpopulation of E9 trigeminal ganglion neurons is NRTN-dependent $(E)$.

absence of Ret staining in these regions. Essentially the same staining pattern was observed in E12 (Fig. 8) as well as in E16 ganglia, suggesting that GFR $\alpha$ protein levels do not change significantly during the developmental stages between E9 and E16.

\section{Retinoic acid induces NRTN-dependent neurite outgrowth and Ret expression}

Given that retinoic acid induces Ret expression in several cell lines in vitro (Tahira et al., 1991; Hishiki et al., 1998), we tested whether retinoic acid would induce NRTN responsiveness from E9 VG, which does not express Ret protein in situ. The VG explants grown for $3 \mathrm{~d}$ in medium containing $10 \mu \mathrm{M}$ retinoic acid and $100 \mathrm{ng} / \mathrm{ml} \mathrm{NRTN} \mathrm{showed} \mathrm{an} \mathrm{extensive} \mathrm{neurite} \mathrm{outgrowth}$ $(947 \pm 110 \mu \mathrm{m})$ in contrast to no outgrowth from explants that were cultured with NRTN alone (Fig. 9). In addition, fibroblastlooking non-neuronal cells that were seen around VG in culture with NRTN alone were not observed in cultures containing NRTN and retinoic acid (Fig. 9). To check whether retinoic acid itself induces neurite outgrowth, we incubated some E9 VG explants with retinoic acid, but without NRTN. Quantitative analysis showed that a significant neurite outgrowth was induced from VG cultured with retinoic acid $(340 \pm 172 \mu \mathrm{m})$ and that the magnitude of neurite outgrowth induced by retinoic acid alone was significantly smaller than that induced by a combination of NRTN and retinoic acid ( $t=2.61 ; p<0.05$; Fig. 9). To examine the possibility that the observed increases in neurite processes were based on Ret protein expression, we labeled the E9 VG neurons for Ret. Dissociated E9 VG neurons cultured for $2 \mathrm{~d}$ in medium containing NRTN and retinoic acid showed a strong Ret staining in their cell bodies (Fig. 9). In contrast, non-neuronal cells in the same culture were devoid of staining, indicating the specificity of Ret induction by retinoic acid.

\section{DISCUSSION}

\section{NRTN is a multimode neurotrophic factor in developing chick cranial ganglia, and its actions are modulated by Ret}

NRTN-induced neurite outgrowth was first detected in CLG neurons at E6, when NRTN has little effect on TG neurons and VG neurons. The CLG neurons showed maximal outgrowth at E6-E9, after which the responsiveness of CLG neurons to NRTN 

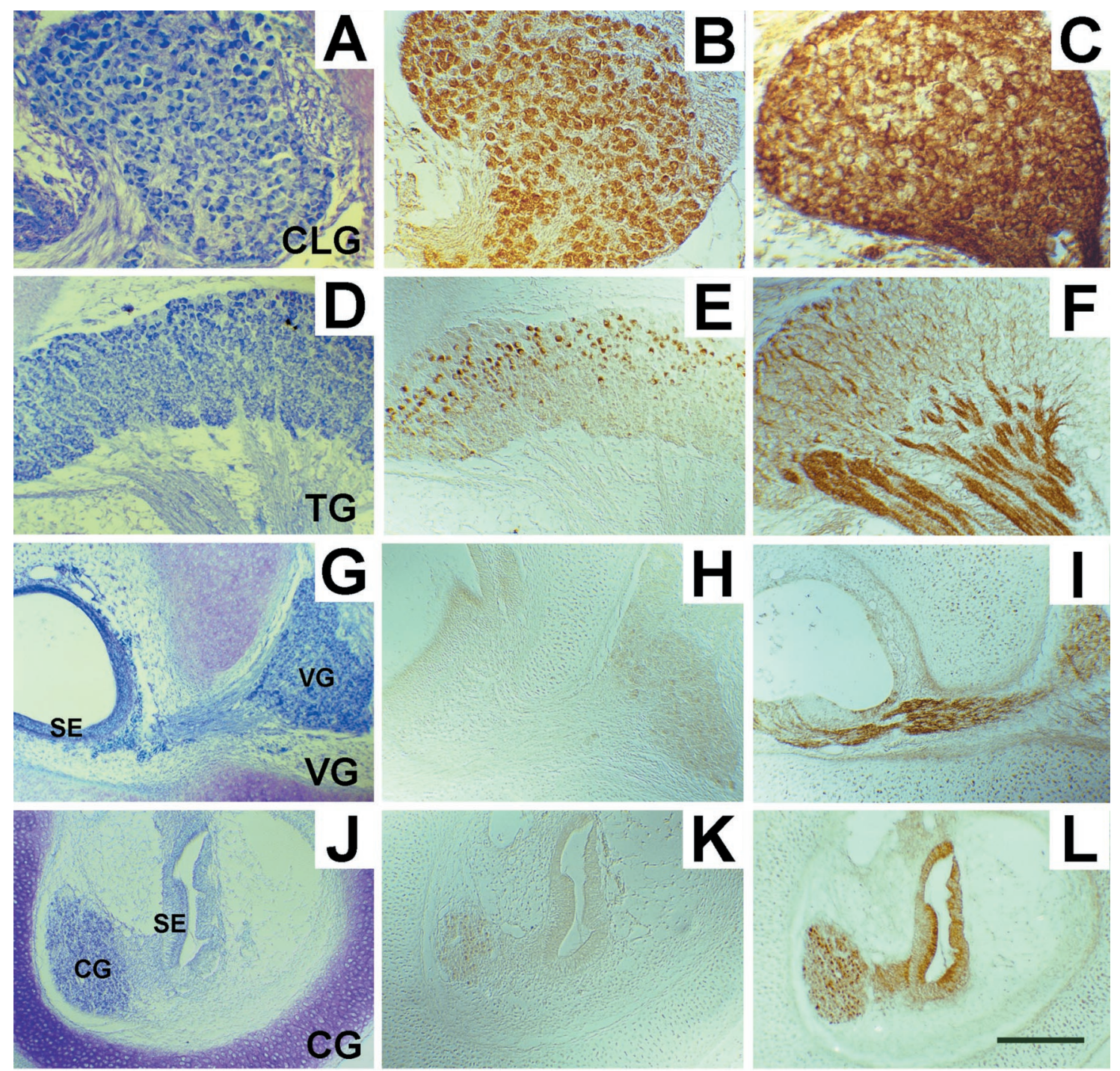

Figure 6. Localization of Ret and GFR $\alpha$ in E9 chick cranial ganglia. Shown are ciliary $(A-C)$, trigeminal $(D-F)$, vestibular $(G, I)$, and cochlear $(J-L)$ ganglia stained with toluidine blue $(A, D, G, J)$, anti-Ret $(B, E, H, K)$, or anti-GFR $\alpha$ antibodies $(C, F, I, L)$. All ciliary ganglion neurons and some trigeminal ganglion neurons are Ret-positive, whereas vestibular as well as cochlear ganglion neurons are devoid of Ret staining. All cranial ganglia that were tested are positive with GFR $\alpha$ staining. Note that Ret labeling is confined to the neuron cell body in contrast with the predominant staining of GFR $\alpha$ in neurites. Scale bar (shown in $L$ ): $A-C, 100 \mu \mathrm{m} ; D-L, 200 \mu \mathrm{m}$. $C L G$, Ciliary ganglion; $T G$, trigeminal ganglion; $V G$, vestibular ganglion; $C G$, cochlear ganglion; $S E$, sensory epithelium; $C G$, cochlear ganglion.

declined and finally became undetectable by E16 (see Fig. 1). The preferential effects of NRTN on early stage CLG neurons are consistent with a previous report showing that GDNF promotes the survival of early stage CLG neurons (Buj-Bello et al., 1995). The early stage effects of NRTN and GDNF, however, differ from the long-lasting effects of CNTF on the CLG neurons. Our observations also indicate that NRTN promotes the outgrowth of midstage (E9-E16) chick TG neurons (see Fig. 1). The stage at which TG neurons started responding to NRTN was later than that of CLG neurons but earlier than that of VG neurons. Positive effects of NRTN were observed in VG neurons at stage E12 and later but were never detected in $\mathrm{CG}$ neurons at any of the developmental stages that were examined. This finding is similar to our recent study (Hashino et al., 1999), in which VG neurons switched their sensitivity from BDNF to GDNF between E12 and E16. GDNF mRNA expression lags behind BDNF mRNA expression in the developing rat cochlea (Pirvola et al., 1992;
Ylikoski et al., 1998), which also suggests that GDNF and NRTN play a major role in late-stage inner ear development.

We first detected Ret immunostaining in CLG at E6 and subsequently in TG at E9 and in VG at E12 (see Fig. 7). The developmental stage at which Ret protein first was detected in various cranial ganglia coincides with the stage at which neurons in the corresponding ganglion started to respond to NRTN (Fig. 10). In each ganglion only a subpopulation of neurons was Retpositive at the time when the protein was first detected. By $3 \mathrm{~d}$ after the first expression, however, the majority of neurons in the ganglion had been labeled with Ret (E9 in CLG, E12 in TG, E16 in VG). In CLG, Ret labeling was very faint at E12 and undetectable at E16 (see Fig. 8), indicating that Ret expression is downregulated in CLG through mid- to late embryonic stages. Collectively, the present results imply a developmental regulation of Ret protein expression in chick cranial ganglia. In addition, Ret-positive cranial ganglion neurons showed a vigorous out- 


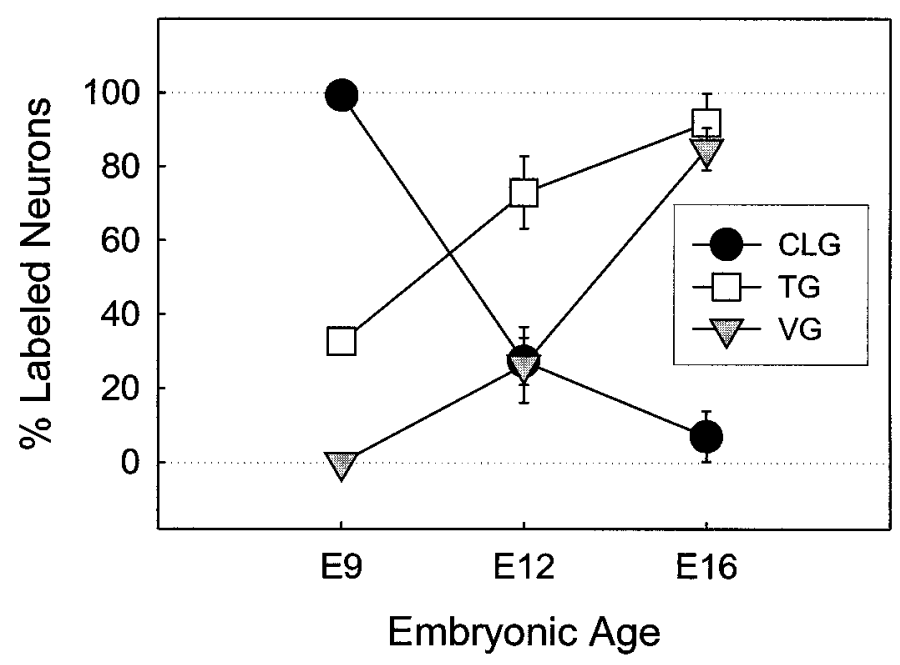

Figure 7. Changes in the number of Ret-positive neurons in ciliary, trigeminal, and vestibular ganglia during development. The graph depicts the percentage of Ret-expressing neurons in each ganglion at various embryonic ages. The percentage of Ret-positive neurons in the ciliary ganglion decreases with age, whereas Ret expression is upregulated in the trigeminal ganglion and vestibular ganglion after E9 and E12, respectively.

growth and survival in the presence of NRTN at 50-100 ng/ml, whereas neurons devoid of Ret (E16 CLG, E6 TG, E9 VG, and E9-E16 CG) showed no neurite outgrowth (see Figs. 1, 7, 10). These results strongly support the assumption that Ret is required for NRTN-mediated cellular responses (Baloh et al., 1997; Klein et al., 1997).

\section{NRTN may be an essential target-derived neurotrophic factor for developing parasympathetic neurons}

The importance of CNTF in parasympathetic neuron development has long been postulated on the basis of its potent survival effects on developing CLG neurons in vitro (Lin et al., 1989; Eckenstein et al., 1990). This assumption, however, has been hampered by several lines of evidence. First, the expression of CNTF, both mRNA and protein, is very low or undetectable during development. CNTF levels first become detectable at postnatal week 2 in rats (Sendtner et al., 1994). In addition, a steep increase in CNTF levels was detected between E10 and E19 in chick eyes (Finn and Nishi, 1996). The time of CNTF synthesis does not coincide with the developmental stage at which trophic support is required for the CLG neurons (the cell death period). Second, a predominant expression of CNTF in myelinating Schwann cells (Rende et al., 1992) contradicts its potential role as a target-derived factor. Third, a gene deletion study showed that CNTF homozygous mice had only a small reduction in motor neurons without any other abnormalities in the PNS or CNS (Masu et al., 1993). More striking evidence has been revealed showing that $\sim 2.5 \%$ of the Japanese population is homozygous for a null mutation of CNTF, which is not associated with any recognizable neurological disorders (Takahashi et al., 1994). Collectively, the currently available data suggest that CNTF may act primarily as a general regulator or maintenance factor for mature PNS neurons (Mitsumoto et al., 1994).

Recent gene deletion studies raised an alternative hypothesis that NRTN is a critical survival factor for parasympathetic neurons. Mutant mice lacking mRNAs for NRTN or its high-affinity receptor, GFR $\alpha 2$, had a similar phenotype exhibiting a substan- tial reduction or loss of parasympathetic innervation (Heuckeroth et al., 1999; Rossi et al., 1999). The present results showing robust effects of NRTN on CLG neuron outgrowth and survival in vitro (see Figs. 2, 5), thus, essentially substantiate the results obtained from the mutant mice. Importantly, positive effects of NRTN on CLG neurons were observed only during the period of target innervation and programmed cell death (see Figs. 1, 10). In addition, a strong expression of NRTN mRNA in the lacrimal and salivary glands (Widenfalk et al., 1997; Golden et al., 1999) and GDNF mRNA in eyes (Buj-Bello et al., 1995) during development further suggests that the synthesis of NRTN and GDNF is regulated developmentally in the target tissues of parasympathetic neurons. Furthermore, a profound localization of the GFR $\alpha$ receptor in distal processes of neurites (see Fig. 6) provides a molecular basis for the retrograde transport of NRTN, although no direct evidence has been provided to support this possibility. Collectively, NRTN fulfills most of the criteria for being considered a target-derived neurotrophic factor that plays a critical role in parasympathetic neuron development.

\section{Ret may be a key gene involved in the segregation of vestibular and cochlear ganglia}

Despite the stage differences, Ret protein was expressed in all cranial and cervical ganglia (nodose, SCG, DRG), with the exception of the cochlear ganglion. Ret was not detected in the chick cochlear ganglion neurons throughout the developmental stages that were tested (E6-E16). In addition, Ret protein also was absent in developing rat cochlear ganglia, which contrasts with an intense Ret labeling in the adjacent vestibular ganglion (M. Shero and E. Hashino, unpublished observations). In support for our observations, Ret mRNA was not detected in either developing or adult rat cochleae (Ylikoski et al., 1998). In this regard, it is interesting to note that vestibular and cochlear ganglia arise originally from one ganglion (vestibocochlear ganglion) that is of placodal origin. The segregated expression of Ret in vestibular versus cochlear ganglion raises the possibility that the Ret gene may play a critical role in the differentiation of $\mathrm{VG}$ and CG. Ret mRNA expression was confined to a region immediately anterior to the otic vesicle in E3-E4 chicks (Robertson and Mason, 1995; Schuchardt et al., 1995) or E9 mice (Pachnis et al., 1993), suggesting that vestibular ganglion neurons start to express Ret mRNA before segregation of the vestibocochlear ganglion (E6-E7 in chicks; E13.5 in mice). Another striking aspect of the present results was that Ret expression is regulated differently in cranial sensory ganglia during development. The temporal order at which Ret protein was first detected in various ganglia is consistent with the observations that Ret mRNA is expressed strictly in a rostrocaudal temporal sequence in chick cranial ganglia (Robertson and Mason, 1995). It should be noted, however, that the first sign of Ret protein expression lags behind, by several days, the first expression of its mRNA. This suggests that additional developmentally regulated genes could be involved in the post-transcriptional processes.

Recent studies have identified several genes that directly or indirectly can regulate Ret expression. Among the candidate genes, certain classes of homeobox genes, such as Phox $2 a$, could regulate Ret expression directly (Morin et al., 1997). Retinoic acid also could regulate Ret expression, because it was shown that the application of retinoic acid in vitro induced a marked increase in Ret mRNA expression from a human neuroblastoma cell line (Tahira et al., 1991). Furthermore, the induction of Ret mRNA 

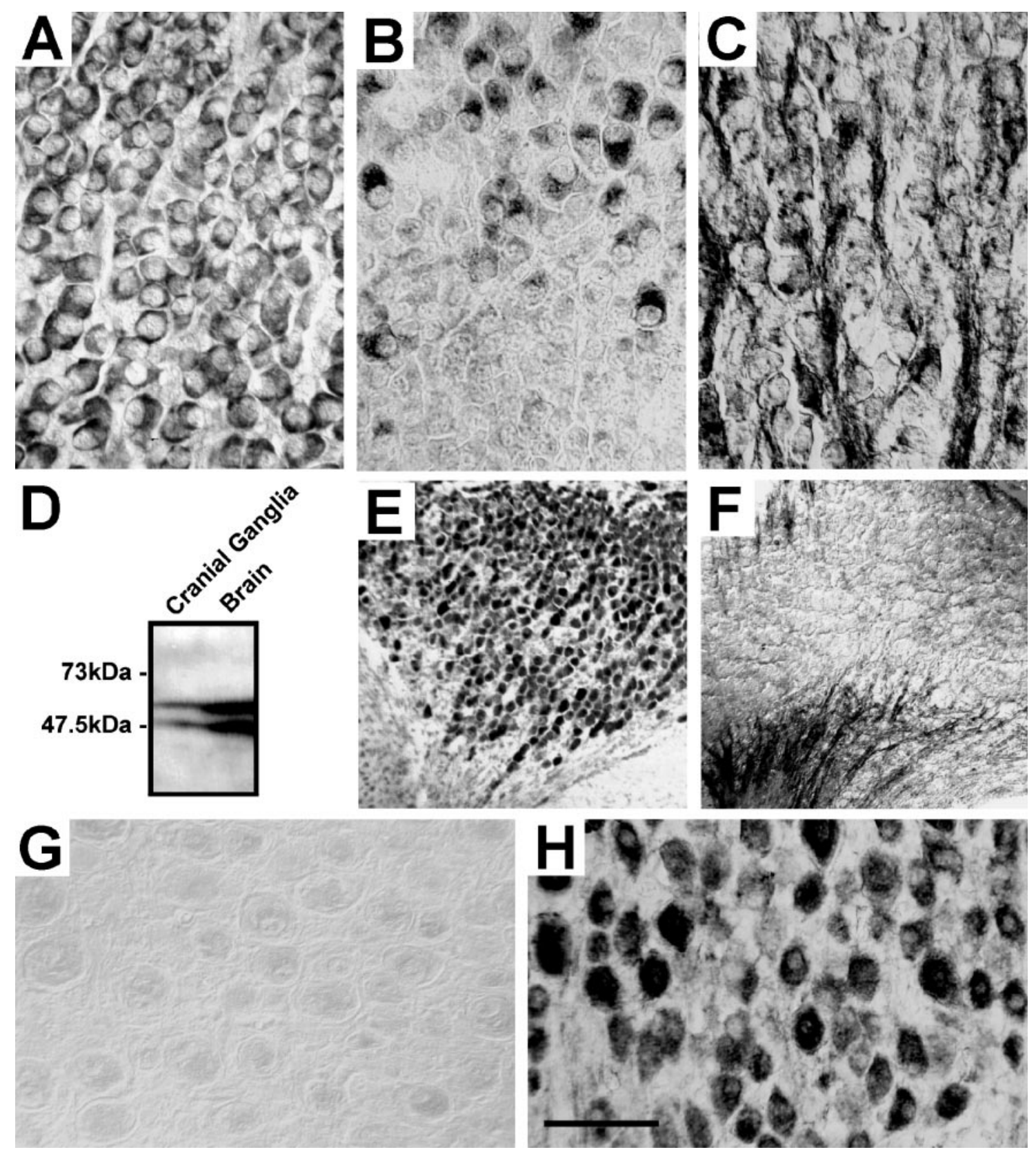

Figure 8. Changes in Ret and GFR $\alpha$ expression in cranial ganglia during development. $A-C$, E9 trigeminal ganglia stained with toluidine blue $(A)$, Ret $(B)$, or GFR $\alpha(C)$. Rostrally located neurons are Ret-positive, but caudally located neurons are devoid of Ret. GFR $\alpha$ is localized predominantly in the neurite processes. $D$, Immunoblots of E9 chick homogenates (cranial ganglia, left; whole brain, right) detected with the GFR $\alpha$ antibody. $E$, $F$, Immunohistochemical localization of Ret $(E)$ and GFR $\alpha(F)$ in E12 trigeminal ganglia. The majority of trigeminal ganglion neurons is Ret-positive at E12 $(E)$ in contrast to a limited number of Ret-positive neurons at E9 (see Fig. 6E). $G, H$, Immunohistochemical staining of Ret in E16 ciliary ( $G$ ) and vestibular $(H)$ ganglia. Ret is absent in ciliary ganglion neurons but is present in vestibular ganglion neurons. Scale bar (shown in $H$ ): $A-C, G, H, 50$ $\mu \mathrm{m} ; E, F, 170 \mu \mathrm{m}$.

expression was associated with neurite outgrowth and an increase in neurofilament mRNA. In agreement with this, we showed that retinoic acid induced neurite outgrowth in response to NRTN from E9 VG neurons, which do not express Ret protein in situ and thus do not show neurite outgrowth in the presence of NRTN (see Fig. 9). The acquisition of NRTN responsiveness appears to be based on the induction of Ret protein expression in the VG neurons. The search for retinoic acid response elements in the Ret gene has been initiated, but has been unsuccessful thus far (Partone et al., 1997).

\section{Conclusion: Ret turns on and off NRTN actions on developing cranial ganglia}

The present study provided evidence that developing chick cranial ganglia have different onset and offset times for NRTN responsiveness and that these times are regulated by Ret protein expression. Ret-positive cranial ganglion neurons showed a vigorous outgrowth in response to NRTN and appeared to be supported by this factor. Ret-positive neurons first were detected in CLG, a most rostrally located ganglion, and subsequently were 

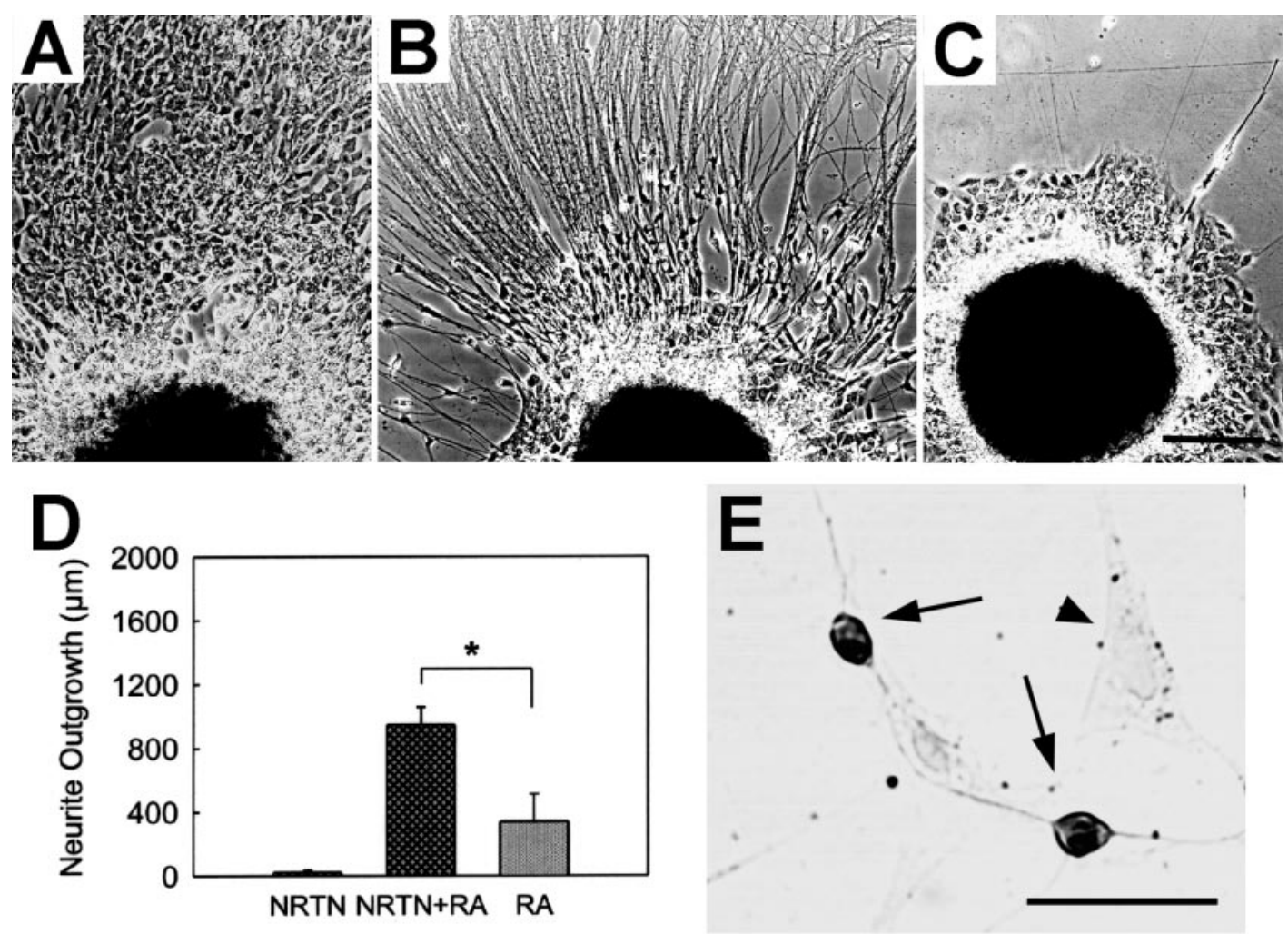

NRTN and/or RA

Figure 9. Effects of retinoic acid (RA) on NRTN responsiveness and Ret protein expression in E9 vestibular ganglion neurons. $A-C$, Phase-contrast micrographs of E9 vestibular ganglion explants cultured with NRTN alone $(A)$, a combination of NRTN and RA $(B)$, or RA alone $(C)$. Scale bar, 200 $\mu \mathrm{m}$. $D$, Graph showing average neurite length $( \pm \mathrm{SE})$ for E9 vestibular ganglion explants in the presence of NRTN alone, a combination of NRTN and RA, or RA alone. $n=8,5,7$ (from left); ${ }^{*} p<0.05$. E, Dissociated E9 vestibular ganglion neurons grown for 48 hr in the presence of NRTN and RA and subsequently stained for Ret. Surviving vestibular ganglion neurons are positive with Ret staining (arrows), whereas a non-neuronal cell is devoid of staining (arrowhead). Scale bar, $50 \mu \mathrm{m}$.

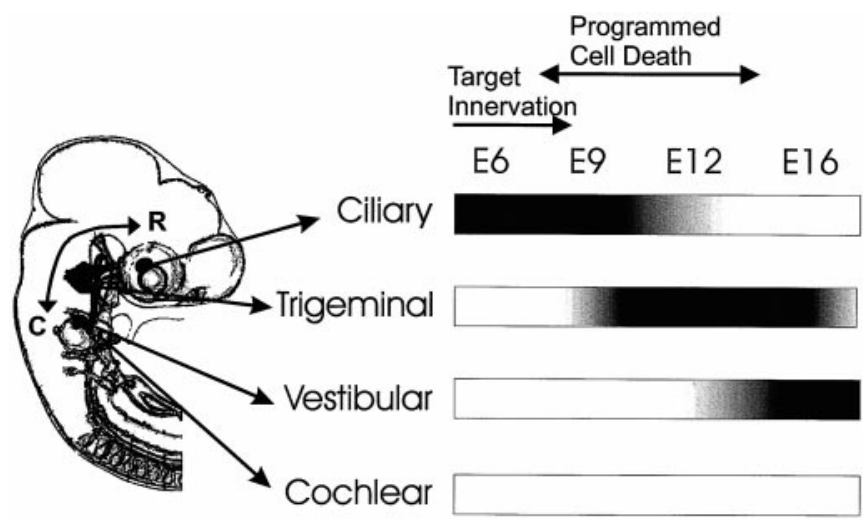

Figure 10. Schematic representation showing developmental changes in NRTN responsiveness of the ciliary, trigeminal, vestibular, and cochlear ganglion neurons (right), and their spatial relationship along the rostrocaudal body axis (left). The darkest area indicates the highest sensitivity; constructed on the basis of Figure 1. The developmental stages at which the cranial ganglion neurons undergo target innervation and programmed cell death [E9-E13 for CLG, Landmesser and Pilar (1974); E8-E14 for VG and CG, Ard and Morest (1984)] are indicated in the figure also. $R$, Rostral; $C$, caudal.

found in other ganglia in the order along the anteroposteral axis of the head during development. Ret was never detected in the cochlear ganglion. Exogenous application of retinoic acid induced NRTN responsiveness from E9 VG neurons, an action that was associated with Ret protein induction. Further investigation is required to determine (1) genes that directly regulate Ret transcription, (2) the interactions of Ret with GFR $\alpha$ receptors, and (3) the functional significance of the differential activation to NRTN (and probably GDNF) responsiveness in various cranial ganglia during development.

\section{REFERENCES}

Ard MD, Morest DK (1984) Cell death during development of the cochlear and vestibular ganglia of the chick. Int $\mathrm{J}$ Dev Neurosci 2:535-547.

Baloh RH, Tansey MG, Golden JP, Creedon DJ, Heuckeroth RO, Keck CL, Zimonjic DB, Popescu NC, Johnson Jr EM, Milbrandt J (1997) TrnR2, a novel receptor that mediates neurturin and GDNF signaling through Ret. Neuron 18:793-802.

Baloh RH, Tansey MG, Lampe PA, Fahner TJ, Enomoto H, Simburger KS, Leitner ML, Araki T, Johnson Jr EM, Milbrandt J (1998) Artemin, a novel member of the GDNF ligand family, supports peripheral and central neurons and signals through the GFR $\alpha 3-$ RET receptor complex. Neuron 21:1291-1302.

Buj-Bello A, Buchman VL, Horton A, Rosenthal A, Davies AM (1995) GDNF is an age-specific survival factor for sensory and autonomic neurons. Neuron 15:821-828.

Buj-Bello A, Adu J, Pinon LGP, Horton A, Thompson J, Rosenthal A, Chinchetru M, Buchman VL, Davies AM (1997) Neurturin responsiveness requires a GPI-linked receptor and the Ret receptor tyrosine kinase. Nature 387:721-724.

Creedon DJ, Tansey MG, Baloh RH, Osborne PA, Lampe PA, Fahrner TJ, Heuckeroth RO, Milbrandt J, Johnson Jr EM (1997) Neurturin shares receptors and signal transduction pathways with glial cell line- 
derived neurotrophic factor in sympathetic neurons. Proc Natl Acad Sci USA 94:7018-7023.

Eckenstein FP, Esch F, Holbert T, Blacher RW, Nishi R (1990) Purification and characterization of a trophic factor for embryonic peripheral neurons: comparison with fibroblast growth factors. Neuron 4:623-631.

Finn TP, Nishi R (1996) Expression of a chicken ciliary neurotrophic factor in targets of ciliary ganglion neurons during and after the cell death phase. J Comp Neurol 366:559-571.

Golden JP, DeMaro JA, Osborne PA, Milbrandt J, Johnson Jr EM (1999) Expression of neurturin, GDNF, and GDNF family receptor mRNA in the developing and mature mouse. Exp Neurol 158:504-528.

Hashino E, Dolnick RY, Cohan CS (1999) Developing vestibular ganglion neurons switch trophic sensitivity from BDNF to GDNF after target innervation. J Neurobiol 38:414-427.

Heuckeroth RO, Enomoto H, Grider JR, Golden JP, Hanke JA, Jackman A, Molliver DC, Bardgett ME, Snider WD, Johnson Jr EM, Milbrandt J (1999) Gene targeting reveals a critical role for neurturin in the development and maintenance of enteric, sensory, and parasympathetic neurons. Neuron 22:253-263.

Hishiki T, Nimura Y, Isogai E, Kondo K, Ichimiya S, Nakamura Y, Ozaki T, Sakiyama S, Hirose M, Seki N, Takahashi H, Ohnuma N, Tanabe M, Nakagawa A (1998) Glial cell line-derived neurotrophic factor/ neurturin-induced differentiation and its enhancement by retinoic acid in human neuroblastomas expressing c-Ret, GFR $\alpha-1$, and GFR $\alpha-2$. Cancer Res 58:2158-2165.

Jing S, Wen D, Yu Y, Holst PL, Luo Y, Fang M, Tamir R, Antonio L, Hu Z, Cupples R, Louis JC, Hu S, Altrock BW, Fox GM (1996) GDNFinduced activation of the Ret protein tyrosine kinase is mediated by GDNFR- $\alpha$, a novel receptor for GDNF. Cell 85:1113-1124.

Jing S, Yu Y, Fang M, Hu Z, Holst PL, Boone T, Delaney J, Schultz H, Zhou R, Fox GM (1997) GFR $\alpha-2$ and GFR $\alpha-3$ are two new receptors for ligands of the GDNF family. J Biol Chem 272:33111-33117.

Klein RD, Sherman D, Ho WH, Stone D, Bennett GL, Moffat B, Vandlen R, Simmons L, Gu Q, Hongo JA, Devaux B, Poulsen K, Armanini A, Nozaki C, Asai N, Goddard A, Phillips H, Henderson CE, Takahashi M, Rosenthal A (1997) A GPI-linked protein that interacts with Ret to form a candidate neurturin receptor. Nature 387:717-721.

Kotzbauer PT, Lampe PA, Heuckeroth RO, Golden JP, Creedon DJ, Johnson Jr EM, Milbrandt J (1996) Neurturin, a relative of glial cell line-derived neurotrophic factor. Nature 384:467-470.

Landmesser L, Pilar G (1974) Synaptic transmission and cell death during normal ganglionic development. J Physiol (Lond) 241:737-749.

Lin LFH, Mismer D, Lile JD, Armes LG, Butler ET, Vannice JL, Collins F (1989) Purification, cloning, and expression of ciliary neurotrophic factor (CNTF). Science 246:1023-1025.

Lin LH, Doherty DH, Lile JD, Bektesh S, Collins F (1993) GDNF: a glial cell line-derived neurotrophic factor for midbrain dopaminergic neurons. Science 260:1130-1132.

Masu Y, Wolf E, Holtmann B, Sendtner M, Brem G, Thoenen H (1993) Disruption of the CNTF gene results in motor neuron degeneration. Nature 365:27-32.

Masure S, Cik M, Pangalos MN, Bonaventure P, Verhasselt P, Lesage AS, Leysen JE, Gordon RD (1998) Molecular cloning, expression, and tissue distribution of glial cell line-derived neurotrophic factor family receptor $\alpha-3$ (GFR $\alpha-3)$. Eur J Biochem 251:622-630.

Milbrandt J, de Sauvage FJ, Fahrner TJ, Baloh RH, Leitner ML, Tansey MG, Lampe PA, Heuckeroth RO, Kotzbauer PT, Simburger KS, Golden JP, Davies JA, Vejsada R, Kato AC, Hynes M, Sherman D, Nishimura M, Wang LC, Vandlen R, Moffat B, Klein RD, Poulsen K, Gray C, Garces A, Johnson Jr EM (1998) Persephin, a novel neurotrophic factor related to GDNF and neurturin. Neuron 20:245-253.

Mitsumoto H, Ikeda K, Klinkosz B, Cedarbaum J, Jesse M, Wong V, Lindsay RM (1994) Arrest of motor neuron disease in wobbler mice cotreated with CNTF and BDNF. Science 265:1107-1110.

Molliver DC, Wright DE, Leitner ML, Prsadanian AS, Doster K, Wen D, Yan Q, Snider WD (1997) IB4-binding DRG neurons switch from NGF to GDNF dependence in early postnatal life. Neuron 19:849-861.

Morin X, Cremer H, Hirsch MR, Kapur RP, Goridis C, Brunet JF (1997) Defects in sensory and autonomic ganglia and absence of locus ceruleus in mice deficient for the homeobox gene Phox2a. Neuron 18:411-423.

Nozaki C, Asai N, Murakami H, Iwashita T, Iwata Y, Horibe K, Klein
RD, Rosenthal A, Takahashi M (1998) Calcium-dependent Ret activation by GDNF and neurturin. Oncogene 16:293-299.

Ohiwa M, Murakami H, Iwashita T, Asai N, Iwata Y, Imai T, Funahashi H, Takagi H, Takahashi M (1997) Characterization of Ret-Shc-Grb2 complex induced by GDNF, MEN 2A, and MEN 2B mutations. Biochem Biophys Res Commun 237:747-751.

Pachnis V, Mankoo B, Costantini F (1993) Expression of the c-ret protooncogene during mouse embryogenesis. Development 119:1005-1017.

Partone G, Puliti A, Bocciardi R, Ravazzolo R, Romeo G (1997) Sequence and characterization of the ret proto-oncogene $5^{\prime}$ flanking region: analysis of retinoic acid responsiveness at the transcriptional level. FEBS Lett 419:76-82.

Pirvola U, Ylikoski J, Palgi J, Lehtonen E, Arumae U, Saarma M (1992) Brain-derived neurotrophic factor and neurotrophin-3 mRNAs in the peripheral target fields of developing inner ear ganglia. Proc Natl Acad Sci USA 89:9915-9919.

Rende M, Muir D, Ruoslahti E, Hagg T, Varon S, Manthrope M (1992) Immunolocalization of ciliary neurotrophic factor in adult rat sciatic nerve. Glia 5:25-32.

Robertson K, Mason I (1995) Expression of Ret in the chicken embryo suggests roles in regionalisation of the vagal neural tube and somites and in development of multiple neural crest and placodal lineages. Mech Dev 53:329-344.

Rossi J, Luukko K, Poteryaev D, Laurikainen A, Sun YF, Laakso T, Eerikainen S, Tuominen R, Lasko M, Rauvala H, Arumae U, Pasternack M, Saarma M, Airaksinen MS (1999) Retarded growth and deficits in the enteric and parasympathetic nervous system in mice lacking GFR $\alpha 2$, a functional neurturin receptor. Neuron 22:243-252.

Schuchardt A, Srinivas S, Pachnis V, Costantini F (1995) Isolation and characterization of a chicken homolog of the c-ret proto-oncogene. Oncogene 10:641-649.

Sendtner M, Carroll P, Holtmann B, Hughes RA, Thoenen H (1994) Ciliary neurotrophic factor. J Neurobiol 25:1436-1453.

Tahira T, Ishizuka Y, Itoh F, Nakayasu M, Sugimura T, Nagao M (1991) Expression of the ret proto-oncogene in human neuroblastoma cell lines and its increase during neuronal differentiation induced by retinoic acid. Oncogene 6:2333-2338.

Takahashi R, Yokoji H, Misawa H, Hayashi M, Hu J, Deguchi T (1994) A null mutation in the human CNTF gene is not causally related to neurological disease. Nat Genet 7:79-84.

Thompson J, Doxakis E, Pinon LG, Strachan P, Buj-Bello A, Wyatt S, Buchman VL, Davies AM (1998) GFR $\alpha$-4, a new GDNF family receptor. Mol Cell Neurosci 11:117-126.

Treanor JJS, Goodman L, Sauvage F, Stone DM, Poulsen KT, Beck CD, Gray C, Armanini MP, Pollock RA, Hefti F, Phillips HS, Goddard A, Moore MW, Buj-Bello A, Davies AM, Asai N, Takahashi M, Vandlen R, Henderson CE, Rosenthal A (1996) Characterization of a multicomponent receptor for GDNF. Nature 382:80-83.

Trupp M, Ryden M, Jornvall H, Funakoshi H, Timmusk T, Areans E, Ibanez CF (1995) Peripheral expression and biological activities of GDNF, a new neurotrophic factor for avian and mammalian peripheral neurons. J Cell Biol 130:137-148.

von Holst A, Lefcort F, Rohrer H (1997) TrkA expression levels of sympathetic neurons correlate with NGF-dependent survival during development and after treatment with retinoic acid. Eur J Neurosci 9:2169-2177.

Widenfalk J, Nosrat C, Tomac A, Westphal H, Hoffer B, Olson L (1997) Neurturin and glial cell line-derived neurotrophic factor receptor- $\beta$ (GDNFR- $\beta$ ), novel proteins related to GDNF and GDNFR- $\alpha$ with specific cellular patterns of expression suggesting roles in the developing and adult nervous system and in peripheral organs. J Neurosci 17:8506-8519.

Worby CA, Vega QC, Chao HH, Seasholtz AF, Thompson RC, Dixon JE (1998) Identification and characterization of GFR $\alpha-3$, a novel coreceptor belonging to the glial cell line-derived neurotrophic receptor family. J Biol Chem 273:3502-3508.

Ylikoski J, Pirvola U, Virkkala J, Suvanto P, Liang XQ, Magal E, Altshuler R, Miller JM, Saarma M (1998) Guinea pig auditory neurons are protected by glial cell line-derived growth factor from degeneration after noise trauma. Hear Res 124:17-26. 